\title{
Global Higher Education in a VUCA World: Concerns and Projections
}

\author{
Robert E. Waller ${ }^{1}$, Pamela A. Lemoine ${ }^{2}$, Evan G. Mense ${ }^{3}$, Christopher J. Garretson ${ }^{1} \&$ Michael D. Richardson ${ }^{1}$ \\ ${ }^{1}$ Educational Leadership, Columbus State University \\ ${ }^{2}$ Educational Leadership, Troy University \\ ${ }^{3}$ Educational Leadership, Southeastern Louisiana University \\ Correspondence: Michael D. Richardson, Professor of Educational Leadership, Columbus State University, 4225 \\ University Drive, Columbus, GA 31907, USA. Tel: 706-325-0612.
}

Received: July 1, 2019

Accepted: July 19, 2019

Online Published: July 24, 2019

doi:10.20849/jed.v3i2.613

URL: https://doi.org/10.20849/jed.v3i2.613

\begin{abstract}
Higher education has faced many challenges since its meager inception. However, higher education today faces its greatest combinations of challenges: economic uncertainty, accountability, globalization and emerging technologies that are daunting to learn and intimidating to implement. VUCA accurately describes this complex, evolving and dynamic environment confronted by global higher education. Therefore, global higher education institutions are attempting to develop the capacity to adapt and modify the new models of knowledge, information and change. In the Industrial Era, work got done in silos with adherence to process and the cult of efficiency. However, this type of working will no longer suffice in an era characterized by flux and change--the VUCA world.
\end{abstract}

Keywords: higher education, globalization, technology, leadership, change, VUCA

\section{Globalization}

Globalization forced higher education institutions to examine their participation in the international milieu and to assess their participation in a seemingly transparent world (Barrett, 2017). Globalization created and encompassed markets and competition between institutions and between nations (Lemoine, Jenkins, \& Richardson, 2017). Global in scale, technology renders the different national systems of higher education more similar to each other in form and organizational behavior. One justification for global access is that competition, performance funding and transparency prepare institutions and systems for a global challenge (Martin, 2017). The globalization of connected networks based on information and communications technologies, created change on an unprecedented scale where technology enabled complex data transfers and information access essential to knowledge-intensive production (Muharlisiani, 2018).

In the modern world, global higher education faces uncertainties due to globalization, the use of contemporary technologies and VUCA which describes the chaotic, turbulent, and rapidly changing education environment, which is the new normal in global higher education (Korsakova, 2019). These external factors require global higher education institutions to respond quickly to the changes (Horney \& O'Shea, 2015; Qureshi \& Nair, 2015). Collectively, they also require the institutions to anticipate the changes and to adapt to them quickly and efficiently by having effective strategies and practices already in place (Richmond, 2015).

Globalization cannot be regarded simply as a higher form of internationalization, rather, globalization transcends national identities and carries the potential to be actively hostile to nation-states (Lumby \& Foskett, 2016; Russell, 2015). One difference between globalization and internationalization is whether national systems become more integrated as suggested by globalization, or more interconnected as with internationalization (Pucciarelli \& Kaplan, 2016).

\section{Globalization and Higher Education}

Global higher education is more open than are national education systems, with a wide range of opportunities for innovations, alliances and markets (Mok, 2015). To maximize effectiveness in the global environment it is essential for institutions to retain a strong sense of identity and purpose; yet be open to and engaged with other 
institutions (Stuart \& Smyre, 2013). At the same time to be effective in the global environment means being prepared to change (Lane, Lemoine, Tinney \& Richardson, 2014). The potential for technology in global higher education coupled with the mobility of people, information and ideas expanded the influence of technology, globalization and higher education (Chan, Mense, Crain-Dorough, Richardson, \& Lane, 2013).

Governments in many nations are wrestling with the question of whether competition at home improves competitiveness abroad, and which combination of competition with collaboration will deliver the best results (Wadhwa, 2016). As a consequence, most governments recognize a relationship between the education of those who enter the work force and their long-term economic competitiveness. Accordingly, the global digital economy requires advanced education forcing colleges and universities to move from more formal traditional roles of teaching and learning to redefining their institutional mission to include innovation, entrepreneurship, creativity and marketing (Wihlborg \& Robson, 2018).

Globalization of the world's economy, increasingly diverse populations, and the pervasive use of technology effects higher education in a myriad of topics (Bass \& Eynon, 2017; Bosire \& Amimo, 2017). However, new digital technologies offer tremendous opportunities for individuals and groups that have the ability to modify and adapt creating greater access to education, new markets for distribution, and expanded income opportunities for higher education institutions (Bano \& Taylor, 2015).

Global universities today confront what may be their greatest challenge as they face globalization, expansion, and economic uncertainty, overlaid by emerging technologies that enable the technologically savvy student body to interact in new ways with content and with each other (Altbach \& Reisberg, 2018). This confluence of factors requires the academy to rethink and restructure, both what and how they teach and research, and how they intersect with society (Osland, Li, \& Mendenhall, 2017; Wilkins \& Juusola, 2018). Global higher education institutions need changes to improve efficiency and stay competitive in the challenges posed by globalization in the VUCA world (Taatila, 2017). These changes occur due to the impact of rapid technological and socio-economic development, including the development of information technology, the trend towards a services-based economy and the knowledge society (Siddiqui, 2014). For the institutions to succeed in a constantly changing world, they need to improve their ability to change rapidly because the ability of the institution to adapt to unexpected changes is critical to achieving and maintaining a competitive advantage (Mok, 2015; Proenza, 2010).

Global higher education systems display many of the same features of a complex adaptive system in that they are constantly under attack by outside forces operating in what is an unstable world affected by volatility, uncertainty, complexity, and ambiguity (Bolman \& Deal, 2015; Johansen \& Euchner, 2013). Higher educational institutions are forced to reshape, respond to and adapt to a rapidly changing environment as a result of learning, adaption, and development (Woodard, Shepherd, Crain-Dorough, \& Richardson, 2011). With globalization, higher education systems are chaotic, turbulent, and changing in milieu of the larger political, social, economic, legal, and cultural context that is fundamentally chaotic (Doyle \& Brady, 2018). Such changes in global higher education have been termed seismic while functioning in the VUCA world (Casey, 2014).

\section{Globalization and Students in the VUCA World}

In the evolving global educational marketplace students are accustomed to instant access, any time, any place learning and sharing (Cheng, 2016). Ubiquitous anytime, anywhere learning is attractive to learners who must balance school and life challenges (Brabazon, 2017). Global universities are using technology as one of the primary means for initiating and maintaining contact with a diverse and changing student population looking for anywhere, anytime learning (Zhao, 2015).

Global higher education institutions must change their traditional mission to remain viable in the new marketplace with different kinds of students (Khan, 2015). The physical university is now a combination multi-dimensional education model: physical and online, or online (Lemoine \& Richardson, 2019). Changes in university instruction are being propelled by two economic forces: marketing to potential new students and competition to recruit, admit and retain those same students (Kemp, 2016).

Calls for accountability and adaptability reach all the way to the castled halls of elite institutions (Nicotea \& Petel, 2016). The admission, retention and preparation of students have become the catch words of the past ten years. Therefore, global higher education institutions are looking for ways to expand their markets and increase the retention of those students admitted (Kruss, McGrath, Peterson, \& Gastrow, 2015). Both of these concerns are being addressed by the use of technology for learning. Digitally mediated information and electronically distributed data have transformed, and will continue to transform, how instruction is designed and delivered, how academic outcomes are measured, and how learning itself is conceived, represented, and studied (Chai \& 
Kong, 2017; Van Nyhuis, 2018). Enhanced online learning has become the new driver in changing higher education learning (Ossiannilsson, 2018). As a result, global higher education faculty must be willing to change and use new forms of technology to reach learners and be facilitators of learning, not dispensers of data (Schiefelbein \& McGinn, 2017).

Today's students have grown up with technology in their everyday lives--computers, cell phones, online games, and social media. Therefore, they expect some technology in everything they do. These technology savvy students often combine full-time employment with part-time study; the so-called earner-learner students (Englund, Olodsson, \& Price, 2017; McPherson \& Bacow, 2015). Financial considerations demand quality instruction for students who will be employable in increasingly competitive markets (Germaine, Richards, Koeller, \& Schubert-Irastorza, 2016). Always before, teaching involved imparting knowledge and teaching students to think. Today faculty are asked to make a paradigm shift; they are asked to teach students to think, but instead of imparting knowledge they now must help students understand where and how to find knowledge, most often using technology (Gallardo-Exhenique, Marques-Molias, Bullen, \& Stribos, 2015).

The higher education system was once the access point for new information and knowledge, now the Internet and social networking technologies offer resources of unparalleled magnitude making information and knowledge gained in classrooms appear outdated (Flavin, 2016). Thus, the focus needs to be on flexibility, learning and development of new knowledge instead of specific solutions. In the push to be globally competitive, most universities, large and small, are tackling the challenges of globalization and VUCA through learning with technology (Cronin, Cochrane, \& Gordon, 2016).

\section{VUCA}

VUCA; volatility, uncertainty, complexity, ambiguity, terms coined for the military world also describes today's global higher education world (Lemoine, Hackett, \& Richardson, 2017; Forsythe, Kuhla, \& Rice, 2018). Higher education leaders in the VUCA world must be activists and innovative where work factors such as adaptability and flexibility are necessary (Breen, 2017; Diefenbach \& Deelman, 2016). VUCA leaders confront societal, financial, management and leadership problems (Chawla \& Lenka, 2018; Mack, Khare, \& Burgartz, 2016). It will be necessary for VUCA leaders to build organizational capacity through new leadership and management theories and application where they must understand society's often contradicting ideas of equity, equality, productivity and diversity (Elkington, Steege, Glick-smith, \& Breen, 2017; Stewart, Khare, \& Schatz, 2016).

Global higher education leaders face the demands and political edicts for increased student achievement as measured by retention or graduation (Rodriguez \& Rodriguez; 2015). In addition, rapid changes in technology are constant and ambiguity reigns as mandates increase (Bawany, 2016). In this lonely and demanding VUCA world global higher education leaders are bombarded with demands for increasing productivity while decreasing cost; built technology infrastructure and capacity to service a global clientele; and increase enrollment to enhance the image of the institution (Elkington, 2018; Prensky, 2014).

\subsection{VUCA Defined}

\subsubsection{Volatility}

Volatility refers to turbulence, or the unexpected, which has increased over the last thirty years with corresponding increases in both intensity and length of the events (Beabout, 2012). There are additional factors which have also added to the increase in turbulence in the global higher education world including: the rise of the digital economy, connectivity, trade liberalization policies around the world, increased global competition and innovation (Brodnick \& Gryskiewicz, 2018).

In the twenty-first century, volatility has shifted the mission of global higher education to ensuring that everyone will be able to adapt to changes in the global labor markets and continue to be employable (Ansell, 2017). Higher education has experienced the emergence of additional colleges either in the form of for-profit universities or other universities in a market that lowers the demand for classes and has brought increased volatility to what had been a stable market (Carillo, 2016).

\subsubsection{Uncertainty}

Uncertainty, or the absence of predictability in both issues and events and the lack of stability does not allow leaders to look to the past for guidance in how to predict future events (Cook, 2015). As an example, budget reductions have led to the loss of faculty and the specter of increasing performance demands for student success. 
Bennett and Lemoine (2014) point out that volatility creates a situation where despite a lack of information; the event's fundamental cause and its effects are known. Therefore change is possible but not always a given. An example could be a university lowering its cost of tuition to attract more students.

\subsubsection{Complexity}

Global higher education organizations in the twenty-first century must manage enormous complexity (Jongbloed, 20150. Three domains of administration are critical for success: (1) Global higher education organizations are increasingly less autonomous; (2) global higher education organizational environments are increasingly complex; and, (3) global higher education organizations are increasingly dependent on technology (Lemoine \& Richardson 2019).

Complexity or the presence of a multitude of possible or difficult to understand causes and other factors both internal and external to the organization are involved in solving problems (Baltaci \& Balci, 2017; Obolensky, 2014). The additional layer of complexity, paired with heightened turbulence, and a lack of easily understood past predictor's increases the difficulty in making good decisions (Moodie, 2016). Uhl-Bien and Arena (2017) add that some information is available, but the sheer volume or form of the data can actually interfere with the ability to process the information. Technological innovations have disrupted the world of global higher education which formerly was open to only a limited few because its products and services were expensive and often inaccessible. That has been transformed to one where accessibility is no longer an issue along with being convenient and it is open to all regardless of wealth or expertise (Khan, 2018). Complexity can be said to create uncertainty because of the sheer volume of possible interactions and outcomes (Arena \& Uhl-Bien, 2016; Hazy \& Backstrom, 2014). Examples include the rules and regulations for higher education in foreign countries or even states with their own unique laws and regulations, cultural values, or educational regulations (Stafford \& Taylor, 2016).

\subsubsection{Ambiguity}

Ambiguity has been defined as a lack of clarity that surrounds an event and its meaning, or the causes behind the things happening which are unclear and difficult to understand. Ambiguity in VUCA could be conceptualized as inability to accurately identify threats and opportunities before they become devastating (Stensaker, Frolich, Huisman, Waagene, Scorat, \& Pimentel Botas, 2014).

Bennett and Lemoine (2014) add that there is a lack of understanding of causal relationships. There are no precedents, so leaders face "unknown unknowns" (p.27). Numerous amounts of data lead a lack of clarity resulting in an incremental approach to problem solving, failing to address the larger fundamental causes that underlie the visible problem. As an example, the twin challenges of escalating information technology costs and the need to avoid technological obsolescence is daunting for global universities in the VUCA world (Hackett, Lemoine, \& Richardson, 2017).

\section{The Influence of Technology in the VUCA World}

Technology ushered in a new era in higher education making knowledge of technology essential for global higher education administrators (Chan, Hackett, Lemoine, \& Richardson, 2016). Technology transformed global higher education by providing a global interconnectedness that restructured educational, social, economic and cultural life (Siu \& Garcia, 2017). Understanding new information and communication technologies are essential for administrators of higher education systems from local, national and global perspectives (Tekleselassie, Roberts, \& Richardson, 2014). In order to open many global markets, higher education institutions are more important than ever to mediate a wide range of relationships and continuous flow of resources (Zhu, 2015). Technology's transformation of global higher education provides a global focus, thereby intensifying the global interconnectedness of higher education institutions (Lemoine, Hackett, \& Richardson, 2016). Although technology has not created international universities, all are impacted by the conceptual and realistic impact of globalism, both in terms of education (instruction) and resources (students) (Devi, Bimol \& Saikia, 2014).

Technology is not a consistent universal phenomenon, but can vary according to management, policy, and government requirements (Dennis, 2018). Continuously extending technology networks based on broad-band Internet and other information and communications technologies (ICTs), are creating new forms of inter-subjective human association, of unprecedented scale and flexibility, spanning cities and nations with varied cultures and levels of economic development (Dave, 2019). Common applications also enable the complex data transfers essential to knowledge-intensive production (Guri-Rosenblit, 2010).

Standards for the utilization of technology in global higher education have been delineated by organizations and accrediting agencies; however, those standards have not always been applied consistently (Fenwick \& Edwards, 
2016). As technology becomes more powerful, faster, and less expensive, there has been a greater need to emphasize effective and efficient utilization of technology and less need to emphasize the technical and practical features (Kaivo-oja \& Lauraeus, 2018). The focus of technology should be to develop the capability and capacity of learning rather than the accumulation of a set of skills, creating a need that ensures students are able to apply learning rather than accumulate a store of knowledge: knowing how instead of knowing what (Bourn, 2018).

As technology has evolved, the world has changed in relation to the technology, and higher education is progressing toward a global platform of delivery, information and accommodation to meet the changing dynamics of the global economy (Esin, 2017). As a result, leaders in global higher education should focus on the quality assurance for technology applications and utilizations rather than continuing the crisis formed by the acquisition of technology (Beerkens, 2015).

\section{Global Higher Education in Transition}

Globalization and the mushrooming of digital technologies accelerated tremendously during the last decade. Current technology clearly provides the means for acquiring greater amounts of information with more efficiency than ever before. Data and information are more readily available and more quickly accessible today, but that does not mean they are used more (Corcoran \& Duane, 2019). Evolving instructional methods and the expansion of e-learning activities allow learners to access, create, and re-create content (Coates, Kelly, \& Naylor, 2017). With increasing challenges of globalization, and evolving technologies, rethinking and restructuring in terms of how to teach is necessary for higher education in this VUCA world (Avdeeva, Kulik, Koareva, Zhilkina, \& Belogurov, 2017).

During the past decade, technical innovations have altered the skills and knowledge needed to succeed in the workplace and society, particularly with online learning (Breslauer \& Hazelhorn, 2016; Kumar, Kumar, Jain Palvia, \& Verma, 2017). Consequently, preparing technically educated and skilled individuals is of great economic importance in the global society and requires significant attention from educators and employers (Bourn, 2018; Teichler, 2017). Global higher education institutions around the world provide students with the knowledge and skills necessary to function in in a global society with varied benefits and challenges (Crosling, Nair, \& Vaithilingam, 2015). Now that society has assumed a global focus, supported by technology, global higher education institutions are asked to offer the highest quality education, especially technological competence, to a widely diverse audience at a cost that can be sustained by society (Joshi, 2017).

\section{Productivity, Globalization and Technology in a VUCA World}

Since the 1980s, universities, in response to government pressure, have become more business-like and enterprising to take advantage of the opportunities presented by the global knowledge economy and information society (Benneworth \& Cunha, 2015). The recent decline in public financial support for higher education is having a significant impact on higher education world-wide (Amy, 2016; Elbasir \& Siddiqul, 2018; Li, 2017). Global higher education institutions seek to meet increasing demands while maintaining the quality of education in a resource constrained environment are being forced to consider two basic strategies: (1) generate additional revenue; and/or (2) increase productivity (Zajda, 2015). Many institutions have increased their revenue generating capacity through tuition increases, private fundraising campaigns, the establishment of "profit centers" and the creation of partnerships with business and industry (Said, Ahmaf, Mustafa, \& Ghani, 2015). However, the ability of universities to increase revenue in these ways is not limitless, as reflected by the negative public reaction to tuition increases which have outpaced inflation for over a decade (Stensaker, 2018). As a result, productivity improvement is increasingly looked to as a long-term response to the problem of constrained resources (Craig, 2015; Teece, Peteraf, \& Leih, 2016). But how is productivity measured? A current attempt is performance funding, based upon the outcomes for students (Schoemaker, Heaton, \& Teece, 2018).

\section{Recommendations for the Future}

Increasingly the only sustainable competitive advantage in global higher education is continuous innovation. In other words, the application of new knowledge (Pearse, 2017). Today, the global higher education system must meet new standards of quality that is being demanded by an increasingly technological and diverse society (Richardson, Jenkins, \& Lemoine, 2017).

In negotiating the $21^{\text {st }}$ Century landscape of global higher education, it is clear that there are four major components that are critical for global higher education leaders to consider in the near future (Froumin \& Lisyutkin, 2018; Sutin \& Jacob, 2016). First, global higher education institutions are becoming increasingly turbulent, disconnected and fragmented (Marginson, 2017). Second, global higher education institutions are increasingly less autonomous and more data-driven in a venue where education is a qualitative endeavor that is 
being mandated as a quantitative measure (Mense, Lemoine, Garretson, \& Richardson, 2018; Marshall, 2018). Third, global higher education is increasingly seen as a social means for a financial goal (Everhart \& Seymour, 2017). Most students are enrolled to get a better job, not to learn about history (Bendixen \& Jacobsen, 2017). Fourth, higher education is increasingly global, driven by technology (Lemoine \& Richardson, 2019).

Global higher education is at a critical juncture of opportunity and growth, coupled with changing demands and changes. Institutions and their leaders must move quickly to adapt to the changes brought about by quality assurance and diminished funding. Each institution must design its own future and how to best adjust and adapt to their individual circumstances. Not all institutions can respond in the identical way.

Also, global higher education institutions must devise means for competing in this new environment. For some, it may be scaling back growth because funding will not permit ideal programs and the ability to meet student needs. For others, it may mean controlled expansion to take advantage of the increased student pool. Regardless, global university must have a strategic plan in place that can be modified in response to the global marketplace, for without a sustainable plan many global universities may not succeed in their current configuration. The opportunities are plentiful, but so are the challenges. Failing to plan for the current and future challenges could be devastating for global universities.

\section{Concluding Thoughts}

VUCA describes the current world of higher education operating in a global marketplace often without a clearly defined mission. Success in a VUCA world is not just about the hardware of technology. It is also about a new kind of leadership that is values-led and purpose-driven. The VUCA world is not going to disappear as technology develops faster and the world truly becomes a global marketplace. Change in the VUCA world is relentless and the environment is constantly shifting.

The VUCA leader's role is to create moments of clarity and focus, whilst at the same time analyzing the shifting environment and preparing to react. Rigidly adhering to current strategy means risk in missing opportunities. VUCA leaders need to be flexible and yet sufficiently focused to keep people motivated. VUCA is complex and challenging, but it is also an environment that can allow true leadership talents to evolve. This will permit VUCA leaders to view VUCA as an opportunity for development and greater collaboration, rather than a risk to be mitigated.

\section{References}

Altbach, P. G., \& Reisberg, L. (2018). Global trends and future uncertainties. Change: The Magazine of Higher Learning, 50(3-4), 63-67.

Amy, L. (2016). Dramatic declines in higher education appropriations: State conditions for budget punctuations. Research in Higher Education, 58(4), 395-429

Ansell, C. (2017). Turbulence, adaptation, and change. In C. K. Ansell, J. Trondal \& M. Ogard (Eds.), Governance in turbulent times (pp. 77-104). London, UK: Oxford University Press.

Arena, M., Uhl-Bein, M. (2016). Complexity leadership theory. Shifting from human capital to social capital. People + Strategy, 39(2), 22-27.

Avdeeva, T. I., Kulik, A. D., Kosareva, L. A., Zhilkina, T. A., \& Belogurov, A. Y. (2017). Problems and prospects of higher education system development in modern society. European Research Studies Journal, 20(4B), 112-124.

Baltaci, A., \& Balci, A. (2017). Complexity leadership: A theoretical perspective. International Journal of Educational Leadership and Management, 5(1), 30-58.

Bano, S., \& Taylor, J. R. (2015). Universities and the knowledge-based economy: Perceptions from a developing country. Higher Education Research and Development, 34(2), 242-255.

Barrett, B. (2017). The dual roles of higher education institutions in the knowledge economy. In B. Barrett (Ed.), Globalization and change in higher education (pp. 57-73). London, UK: Palgrave Macmillan.

Bass, R., \& Eynon, B. (2017). From unbundling to rebundling: Design principles for transforming institutions in the new digital ecosystem. Change: The Magazine of Higher Learning, 49(2), 8-17.

Bawany, S. (2016). Leading change in today's VUCA world. Leadership Excellence Essentials, 33(2), 31-2.

Beabout, B. R. (2012). Turbulence, perturbance, and educational change. Complicity: An International Journal of Complexity and Education, 9(2). 
Beerkens, M. (2015). Quality assurance in the political context: In the midst of different expectations and conflicting goals. Quality in Higher Education, 21(3), 231-250.

Bendixen, C., \& Jacobsen, J. C. (2017). Nullifying quality: The marketisation of higher education. Quality in Higher Education, 23(1), 20-34.

Bennett, N., \& Lemoine, J. (2014). What VUCA really means for you. Harvard Business Review, 92(1/2), 27.

Benneworth, P., \& Cunha, J. (2015). Universities' contributions to social innovation: Reflections in theory \& practice. European Journal of Innovation Management, 18(4), 508-527.

Bolman, L. G., \& Deal, T. E. (2015). Think--or sink: Leading in a VUCA world. Leader to Leader, 2015(76), $35-40$.

Bosire, J., \& Amimo, C. (2017). Emerging issues and future prospects in the management of transnational education. International Journal of Higher Education, 6(5), 143.

Bourn, D. (2018). Globalisation, education and skills. In Understanding global skills for 21 st century professions (pp. 17-35). Cham, Switzerland: Palgrave Macmillan.

Brabazon, T. (2017). From digital disruption to educational excellence: Teaching and learning in the knowledge economy. International Journal of Social Sciences \& Educational Studies, 3(3), 188-203.

Breen, J. M. (2017). Leadership resilience in a VUCA world. In Visionary leadership in a turbulent world: Thriving in the new VUCA context (pp. 39-58). Bingley, UK: Emerald Publishing Limited.

Breslauer, T., \& Hazelkorn, E. (2016). Globalization broadens higher education. International Educator, 25(4), $18-21$.

Brodnick, R., \& Gryskiewicz, S. (2018). Using positive turbulence for planning and change. Planning for Higher Education, 46(4), 27-40.

Carrillo, F. J. (2016). Knowledge markets: a typology and an overview. International Journal of Knowledge-Based Development, 7(3), 264-289.

Casey, G. W. (2014). Leading in a 'VUCA' world. Volatility. uncertainty. chaos. ambiguity. Fortune, 169(5), 75-76.

Chai, C. S., \& Kong, S. C. (2017). Professional learning for 21 st century education. Journal of Computers in Education, 4(1), 1-4.

Chan, T. C., Hackett, P. T., Lemoine, P. A., \& Richardson, M. D. (2016). The use of technology in higher education: The role of accountability. Journal of Studies in Educational Leadership, 2(1).

Chan, T. C., Mense, E. G., Crain-Dorough, M., Richardson, M. D., \& Lane, K. E. (2013). Observations through a keyhole: The changing dimension of global higher education. In S. Mukerji, \& P. Tripathi (Eds.), Handbook of research on transnational higher education management. (pp. 59-78). Hershey, PA. IGI.

Chawla, S., \& Lenka, U. (2018). Leadership in VUCA environment. In Flexible strategies in VUCA markets (pp. 213-224). Singapore: Springer.

Cheng, Y. C. (2016). Paradigm shift in higher education: Learning, internationalisation and development. In Globalisation and higher education reforms (pp. 115-132). Cham, Switzerland: Springer.

Coates, H., Kelly, P., \& Naylor, R. (2017). Leading online education for student success. International Journal of Chinese Education, 6(1), 105-126.

Cook, P. (2015). Leading in a VUCA world. London, UK: TTM Associates.

Corcoran, N., \& Duane, A. (2019). Organizational knowledge sharing and enterprise social networks: A higher education context. In Educational and social dimensions of digital transformation in organizations (pp. 78-114). Hershey, PA: IGI Global.

Craig, R. (2015). College disrupted: The great unbundling of higher education. New York, NY: Macmillian.

Cronin, C., Cochrane, T., \& Gordon, A. (2016). Nurturing global collaboration and networked learning in higher education. Research in Learning Technology, 24(1), 264-297.

Crosling, G., Nair, M., \& Vaithilingam, S. (2015). A creative learning ecosystem, quality of education and innovative capacity: A perspective from higher education. Studies in Higher Education, 40(7), 1147-1163 
Dave, D. (2019). An analytical study of the role of ICT in higher education. Journal of Global Economy, 15(1), 56-61.

Dennis, M. J. (2018). The impact of technology on US and worldwide higher education. Enrollment Management Report, 21(10), 1-3.

Devi, L. P., Bimol, S., \& Saikia, M. (2014). Information and communication technology influence in education system. International Journal of Information Technology \& Computer Sciences Perspectives, 3(4), 1265.

Diefenbach, S., \& Deelmann, T. (2016). Organizational approaches to answer a VUCA world. In Managing in a VUCA world (pp. 197-208). Cham, Switzerland: Springer.

Doyle, T., \& Brady, M. (2018). Reframing the university as an emergent organisation: Implications for strategic management and leadership in higher education. Journal of Higher Education Policy and Management, 40(4), 305-320.

Elbasir, A., \& SiddiquI, K. (2018). Higher education, funding, polices and politics: A critical review. Journal of Social and Administrative Sciences, 5(2), 152-167.

Elkington, R. (2018). Leadership decision-making leveraging big data in VUCA contexts. Journal of Leadership Studies, 12(3), 66-70.

Elkington, R., Steege, M. V. D., Glick-Smith, J., \& Breen, J. M. (Eds.). (2017). Visionary leadership in a turbulent world: Thriving in the new VUCA context. Bingley, UK: Emerald Publishing Limited.

Englund, C., Olofsson, A. D., \& Price, L. (2017). Teaching with technology in higher education: Understanding conceptual change and development in practice. Higher Education Research \& Development, 36(1), 73-87.

Esin, J. O. (2017). System overview of cyber-technology in a digitally connected global society. Bloomington, IN: AuthorHouse.

Everhart, D., \& Seymour, D. M. (2017). Challenges and opportunities in the currency of higher education. In Handbook of research on competency-based education in university settings (pp. 41-65). Hershey, PA: IGI Global.

Fenwick, T., \& Edwards, R. (2016). Exploring the impact of digital technologies on professional responsibilities and education. European Educational Research Journal, 15(1), 117-131.

Flavin, M. (2016). Technology-enhanced learning and higher education. Oxford Review of Economic Policy, $32(4), 632-645$.

Forsythe, G., Kuhla, K., \& Rice, D. (2018). Can you do VUCA? 5 Key strategies for success. Chief Executive, 294, 41-50.

Froumin, I., \& Lisyutkin, M. (2018). State and world-class universities: Seeking a balance between international competitiveness, local and national relevance. In World-class universities (pp. 243-260). Leiden, The Netherlands: Brill Sense.

Gallardo-Exhenique, E. E., Marques-Molias, L., Bullen, M., Stribos, J. (2015). Let's talk about digital learners in the digital era. International Review of Research in Open \& Distance Learning, 16(3), 156-187.

Germaine, R., Richards, J., Koeller, M., \& Schubert-Irastorza, C. (2016). Purposeful use of 21st Century skills in higher education. Journal of Research in Innovative Teaching, 9(1).

Guri-Rosenblit, S. (2010). Digital technologies in higher education: Sweeping expectations and actual effects. New York, NY: Nova Science.

Hackett, P. T., Lemoine, P. A., \& Richardson, M. D. (2017). Impact of technology ambiguity on leadership in global higher education. In Encyclopedia of strategic leadership and management (pp. 270-281). Hershey, PA: IGI Global.

Hazy, J., \& Backström, T. (2014). Complexity and human interaction dynamics. Complexity, 15(4).

Horney, N., \& O'Shea, T. (2015). Focused, fast and flexible: Creating agility advantage in a VUCA world. Meadville, PA: BookBaby.

Johansen, B., \& Euchner, J. (2013). Navigating the VUCA world. Research Technology Management, 56(1), 10-15.

Jongbloed, B. (2015). Universities as hybrid organizations: Trends, drivers, and challenges for the European university. International Studies of Management \& Organization, 45(3), 207-225. 
Joshi, M. (2017). Invention, innovation and innovative practices: A reason to study in a VUCA perspective. Journal of Entrepreneurship, Business and Economics, 5(2), 87-109.

Kaivo-oja, J. R. L., \& Lauraeus, I. T. (2018). The VUCA approach as a solution concept to corporate foresight challenges and global technological disruption. Foresight, 20(1), 27-49.

Kemp, N. (2016). The international education market: Some emerging trends. International Higher Education, (85), 13-15.

Khan, A. U. (2015). What globalization means for the education sector: How do we cater to emerging needs? Emerging Economy Studies, 1(1), 96-107.

Khan, S. (2018). Strategies to meet the challenges of global education: Prospects of Asian higher education. Asian Higher Education Chronicles, 1(1), 31-36.

Korsakova, T. V. (2019). Higher education in VUCA world: New metaphor of university. European Journal of Interdisciplinary Studies, 5(2), 31-35.

Kruss, G., McGrath, S., Petersen, I. H., \& Gastrow, M. (2015). Higher education and economic development: The importance of building technological capabilities. International Journal of Educational Development, 43, 22-31.

Kumar, A., Kumar, P., Jain Palvia, S. C., \& Verma, S. (2017). Online education worldwide: Current status and emerging trends. Journal of Information Technology Case and Application Research, 19(1), 1-9.

Lane, K. E., Lemoine, P. A., Tinney, T. M., \& Richardson, M. D. (2014). Modify and adapt: Global higher education in a changing economy. International Journal of Innovation in the Digital Economy (IJIDE), 5(2), 24-36.

Lemoine, P. A., Hackett, P. T., \& Richardson, M. D. (2017). Global higher education and VUCA-volatility, uncertainty, complexity, ambiguity. In Handbook of research on administration, policy, and leadership in higher education (pp. 549-568). Hershey, PA: IGI Global.

Lemoine, P. A., Hackett, T., \& Richardson, M. D. (2016). Higher education at a crossroads: Accountability, globalism and technology. In Handbook of research on quality assurance and value management in higher education (pp. 27-57). Hershey, PA: IGI Global.

Lemoine, P. A., Jenkins, W. M., \& Richardson, M. D. (2017). Global higher education: Development and implications. Journal of Education and Development, 1(1), 58-71.

Lemoine, P. A., \& Richardson, M. D. (2019). Creative disruption in higher education: Society, technology, and globalization. In Educational and social dimensions of digital transformation in organizations ( $\mathrm{pp}$. 275-293). Hershey, PA: IGI Global.

Li, A. Y. (2017). Dramatic declines in higher education appropriations: State conditions for budget punctuations. Research in Higher Education, 58(4), 395-429.

Lumby, J., \& Foskett, N. (2016). Internationalization and culture in higher education. Educational Management Administration \& Leadership, 44(1), 95-111.

Mack, O., Khare, A., Krämer, A., \& Burgartz, T. (2016). Managing in a VUCA world. Cham, Switzerland: Springer

Marginson, S. (2017). The world-class multiversity: Global commonalities and national characteristics. Frontiers of Education in China, 12(2), 233-260.

Marshall, S. J. (2018). Shaping the university of the future. New York, NY: Springer.

Martin, W. J. (2017). The global information society. New York, NY: Taylor \& Francis.

McPherson, M.S., \& Bacow, L. S. (2015). Online higher education: Beyond the hype cycle. Journal of Economic Perspectives, 29(4), 135-154.

Mense, E. G., Lemoine, P. A., Garretson, C. J., \& Richardson, M. D. (2018). The development of global higher education in a world of transformation. Journal of Education and Development, 2(3), 47.

Mok, K. H. (2015). Higher education transformations for global competitiveness: Policy responses, social consequences and impact on the academic profession in Asia. Higher Education Policy, 28(1), 1-15.

Moodie, G. (2016). Universities, disruptive technologies, and continuity in higher education: The impact of information revolutions. New York, NY: Springer. 
Muharlisiani, L. T. (2018). Capacity building toward global competitiveness. Journal of Management Info, 5(3), 8-11.

Nicotra, A. \& Patel, F. (2016). Contesting the political economy of higher education: Educating the good citizen. Journal of International and Global Studies, 7(2), 22-39.

Obolensky, M. N. (2014). Complex adaptive leadership: Embracing paradox and uncertainty. Aldershot, UK: Gower Publishing, Ltd.

Osland, J. S., Li, M., \& Mendenhall, M. E. (2017). Patterns, themes and future directions for advancing global leadership. In Advances in global leadership (pp. 253-262). Somerville, MA; Emerald Publishing Limited.

Ossiannilsson, E. (2018). Promoting active and meaningful learning for digital learners. In Handbook of research on mobile technology, constructivism, and meaningful learning (pp. 294-315). Hershey, PA: IGI Global.

Pearse, N. J. (2017). Change management in a VUCA world. In Visionary leadership in a turbulent world: Thriving in the new VUCA context (pp. 81-105). Somerville, MA: Emerald Publishing Limited.

Prensky, M. (2014). VUCA: Variability, uncertainty, complexity, ambiguity. Educational Technology, 54(2), 64-64.

Proenza, L. M. (2010). Relevance, connectivity, and productivity: Three paths to innovation in higher education. Innovations, 5(2), 3-11.

Pucciarelli, F., \& Kaplan, A. (2016). Competition and strategy in higher education: Managing complexity and uncertainty. Business Horizons, 59(3), 311-320.

Qureshi, R., \& Nair, S. (2015). The role of higher education in emerging knowledge society. Global Journal on Humanities and Social Sciences, 1(1).

Richardson, M. D., Jenkins, W. M., \& Lemoine, P. A. (2017). Planning for innovation and disruption in a global environment. Educational Planning, 23(3), 11-24.

Richmond, R. C. (2015). The future of the university is change. In G. A. Olson \& W. Presley (Eds.), Future of higher education: Perspectives from America's academic leaders (pp. 31-41). New York, NY: Routledge.

Rodriguez, A., \& Rodriguez, Y. (2015). Metaphors for today’s leadership: VUCA world, millennial and “Cloud Leaders". Journal of Management Development, 34(7), 854-866.

Russell, E. (2015). The internationalization of emerging market higher education providers: Exploring transnational provision. International Journal of Business and Society, 16(2), 261-280.

Said, H., Ahmad, I., Mustaffa, M. S., \& Ghani, F. A. (2015). Role of campus leadership in managing change and challenges of internationalization of higher education. Mediterranean Journal of Social Sciences, 6(4), 82.

Schiefelbein, E., \& McGinn, N. F. (2017). Learning to educate: Proposals for the reconstruction of education in developing countries. Cham, Switzerland: Springer.

Schoemaker, P. J., Heaton, S., \& Teece, D. (2018). Innovation, dynamic capabilities, and leadership. California Management Review, 61(1), 15-42.

Siddiqui, K. (2014). Higher education in the era of globalization. International Journal of Humanities and Social Science, 3(2), 9-32

Siu, K. W. M., \& García, G. J. C. (2017). Disruptive technologies and education: Is there any disruption after all?. In Educational leadership and administration: Concepts, methodologies, tools, and applications (pp. 757-778). Hershey, PA: IGI Global.

Stafford, S., \& Taylor, J. (2016). Transnational education as an internationalisation strategy: Meeting the institutional management challenges. Journal of Higher Education Policy and Management, 38(6), 625-636.

Stensaker, B. (2018). Quality assurance and the battle for legitimacy-Discourses, disputes and dependencies. Higher Education Evaluation and Development, 12(2), 54-62.

Stensaker, B., Frølich, N., Huisman, J., Waagene, E., Scordato, L., \& Pimentel Bótas, P. (2014). Factors affecting strategic change in higher education. Journal of Strategy and Management, 7(2), 193-207.

Stewart, B., Khare, A., \& Schatz, R. (2016). Volatility, uncertainty, complexity and ambiguity in higher education. In Managing in a VUCA world (pp. 241-250). Cham, Switzerland: Springer. 
Stuart, L., \& Smyre, R. (2013). Leadership in transformation: Building capacities for a new age. International Journal of Interdisciplinary Education, 1(1).

Sutin, S. E., \& Jacob, W. J. (2016). Strategic transformation of higher education: Challenges and solutions in a global economy. Boston, MA: Rowman \& Littlefield.

Taatila, V. (2017). Paradigm shift in higher education? On the Horizon, 25(2).

Teece, D., Peteraf, M., \& Leih, S. (2016). Dynamic capabilities and organizational agility: Risk, uncertainty, and strategy in the innovation economy. California Management Review, 58(4), 13-35.

Teichler, U. (2017). Internationalisation trends in higher education and the changing role of international student mobility. Journal of International Mobility, 1(5), 177-216.

Tekleselassie, A. A., Roberts, E. L., \& Richardson, M. D. (2014). Technology as educational speculation: Mechanism for a continually shifting world. In S. S. Shepherd, P. A. Lemoine, W. Ennis, III, M. D. Richardson, \& J. H. Fulwiler (Eds.). Innovative technology for $21^{\text {st }}$ Century education. Dubuque, IA: Kendall/Hunt.

Uhl-Bien, M., \& Arena, M. (2017). Complexity leadership: Enabling people and organizations for adaptability. Organizational Dynamics, 46(11), 9-20.

Van Nyhuis, A. (2018). Advancing globalization by teaching with technology: Synthesizing global understanding and collaborative online international learning models. American Association of University Administrators, 33(1), 136-143.

Wadhwa, R. (2016). New phase of internationalization of higher education and institutional change. Higher Education for the Future, 3(2), 227-246.

Wihlborg, M., \& Robson, S. (2018). Internationalisation of higher education: Drivers, rationales, priorities, values and impacts. European Journal of Higher Education, 8(1), 8-18.

Wilkins, S., \& Juusola, K. (2018). The benefits \& drawbacks of transnational higher education: Myths and realities. Australian Universities' Review, 60(2), 68-76.

Woodard, H. C., Shepherd, S. S., Crain-Dorough, M., \& Richardson, M. D. (2011). The globalization of higher education: Through the lens of technology and accountability. I-manager's Journal of Educational Technology, 8(2), 16-24.

Zajda, J. (2015). Globalisation and its impact on education and policy. In J. Zaida (Ed.), Second international handbook on globalisation, education and policy research (pp. 105-125). Dordrecht, Netherlands: Springer.

Zhao, Y. (2015). A world at risk: An imperative for a paradigm shift to cultivate 21st Century learners. Society, 52(2), 129-135.

Zhu, C. (2015). Organisational culture and technology-enhanced innovation in higher education. Technology, Pedagogy and Education, 24(1), 65-79.

\section{Copyrights}

Copyright for this article is retained by the author(s), with first publication rights granted to the journal.

This is an open-access article distributed under the terms and conditions of the Creative Commons Attribution license (http://creativecommons.org/licenses/by/4.0/). 